II (i) To support those psychiatrists and social workers trying to implement carefully planned discharged policies. We want discharge to a known address, and to a caring person, and a continuing liaison with the medical and social services. This could be far more cost effective than precipitate discharge resulting from excessive pressure to reduce in-patient beds. Too rapid discharge, and consequent re-admission to hospital (see 5(iii) above) - if re-admission is possible-make any chance of rehabilitation more difficult to achieve.

(ii) To expand the Community Psychiatric Nursing Service so that it is available to the mentally ill all over the country, and also to relatives and others providing accommodation and day to day care. This service, which has the confidence of all, should improve access to specialized medical help, including hospital re-admission, where the condition of the patient worsens beyond the ability of families and others to cope. Hospital catchment area boundaries should not be used as barriers to admission for treatment.

(iii) To support vigorously and financially various kinds of realistic alternatives to hospital provision, now often in outworn buildings (which may be provided by local authorities, voluntary bodies or families), bearing in mind that: (a) a minority of patients will need a very great deal of hospital or hostel care, with high staffing levels, which may well be required on a lifelong basis; (b) that a good number of patients living in the community will be unable to maintain themselves without ongoing and caring support; and (c) that many patients suffering severe emotional distress need easy access to short-term good quality hostel care.

\title{
Correspondence
}

\section{Hospital records and psychiatric memorabilia}

\section{DEAR SIRS}

I was interested to see Martin Guha's article on 'Archives and Historical Libraries in Psychiatry' (Bulletin, February $1984,8,25)$. As custodian of what he kindly refers to as 'almost certainly the largest collection of this sort of material in this country', I would like to add some further information.

Almost by the way, the historical book collection at the Institute of Psychiatry was originally based not on Willi Mayer-Gross's library, though that may have provided the bulk of it, but on the library of Henry Maudsley himself. This was presumably the source of, for example, the association's copies of books formerly belonging to his father-in-law, John Conolly. Following Maudsley's specific wishes, over 200 of his 'philosophical, psychological and medical works', together with a bust of Shakespeare and 15 framed prints of 'distinguished alienists' were given to the Maudsley Hospital after his death by his nephew and executor. They were selected by Sir Frederick Mott, and the books were intended to be kept in a specially inscribed case as a memorial to him. Unfortunately they seem now to have been dispersed among the rest of the historical books by $\mathrm{Mr}$ Guha's predecessors, which is particularly sad in view of the singular lack of personal information about Henry Maudsley. The real value of association copies is not in the signature at the front, but in what they can tell of the owner's intellectual pursuits and interests, and the influences behind his own work, and to have been able to reconstruct at least part of Maudsley's library would have been very useful to his would-be biographers.

Mr Guha's references to 'collections' of archives and 'archival and historical collections' might be slightly misleading. Archives are simply the accumulated records of an organization or an individual, and are quite different from the artificial collections of manuscripts which are often to be found in libraries. Thus the archives here are no more nor less than the historical records of Bethlem itself and of the Maudsley: they are only larger than most psychiatric hospital archives because Bethlem is very old, and paper does tend to mount up!

The records of psychiatric hospitals, as of all NHS hospitals, are Public Records, and subject to the provisions of the Public Records Act 1958. The archives of individual hospitals should therefore not be difficult to locate, if the rules have been followed. If they have not been destroyed (and destruction is generally not in accordance with the rules), they should be either still in the hospital, or deposited in a place appointed by the Lord Chancellor as a repository for Public Records - in this case usually the County or other Local Record Office. Bethlem, as one of the only two hospitals in the country to employ a full-time professional archivist, has been appointed as the official repository of its own records, otherwise they would probably be in the Guildhall Library or the GLC Record Office.

Of course, should one apply first to the hospital itself, getting anyone to admit to knowing where the archives are is a different matter: it is therefore probably wise to start with the relevant County Record Office. There has lately been a considerable effort by local archivists to establish contact with the hospitals in their areas, and even if the records have not actually come into the Record Office, they will often know what is available and where. Local Record Offices sometimes also contain other material of interest to historians of psychiatry, such as the records of private 
madhouses, family papers, Quarter Sessions records, etc., and anyone who already knows roughly what they are looking for should always start their enquiries in what appears to be the appropriate locality.

I cannot share Mr Guha's regrets that there is no "central archive' to act as a focus for research in the history of psychiatry, knowing this to be quite impossible from the very nature of archives. The particular records relating to George III to which he refers, for example, are in Lambeth Palace Library because the Archbishop of Canterbury headed the 'Queen's Council' which was appointed to take care of the King's person during his illness, and they are therefore part of the archives of the Archbishops of Canterbury. They might just as validly be carted off to a 'central archive' for the study of the work of Royal Consorts, as to a centre for the study of psychiatric history: as it is, one does at least know where to look for them. And anyone who has read Hunter and Macalpine on the subject will know that material relating to the King's illness is to be found scattered around, quite properly, in innumerable places, as is the case with the sources for virtually any historical subject. There is much essential information about Bethlem's early history in the City of London Records, and some in the Public Record Office, for example.

All that can be hoped for is the centralization of information about where such material is to be found, which is made increasingly possible by the advent of computers, but is, alas, still some way off for this particular branch of historical research. Meanwhile, it is an unfortunate truism that the more you know about the subject you are researching, the more likely you are to know where to find the material. The situation has not changed much since John Selden wrote in the seventeenth century: 'Out of their own nature it is known to men that are acquainted with Records where they are'.

Patricia Allderidge

The Archives

Bethlem Royal and Maudsley Hospitals

Beckenham, Kent

\section{DEAR SIRS}

I was very interested to read Dr Henry R. Rollin's appeal to preserve psychiatric memorabilia (Bulletin, February $1984,8,36$ ). I am sure he is absolutely right that there is a grave danger that important and irreplaceable items may be destroyed in the process of closures. The experience at Warwick has been that the County Record Office has, indeed, been very glad to take documents of historical importance, including clinical records, and has taken great trouble in cataloguing and storing these. They are now available for scrutiny to bona fide interested persons, including researchers, but not others.

Apart from preservation, there is the danger that clinical records may find their way on to the open market and create problems with all that this implies with regard to confidentiality, particularly in areas where the population is still relatively static. Recently, in the catalogue of a medical antiquarian bookseller, clinical records from a psychiatric institution which had been closed down were advertised. I feel that there is a need for the College to approach the DHSS to see if an appropriate policy for important documents, particularly clinical records, can be formulated.

The Central Hospital

T. L. DUNN

\section{Appeal for old medical journals}

Dr Tamba Matturi of Bo in Sierra Leone appeals for back copies of psychiatric and general medical journals. He qualified at the Royal College of Surgeons in Dublin in 1969, and from 1973-78 did postgraduate training in psychiatry in the USA.

Dr Matturi is trying to establish a clinic in Bo (Sierra Leone's second city), and much of his practice is psychiatric. Like most developing countries, psychiatry is poorly funded in Sierra Leone, and the only mental hospital in the country (for 4 million people!) is bursting at the seams. Dr Matturi is using anti-psychotic drugs brought back from America in
1978 - they are nearly finished and there is no prospect of importing more. Members who have worked in developing countries will have first-hand experience of Dr Matturi's position. They will know the difficulties of good psychiatric practice and the isolation from other psychiatrists and current developments in the specialty.

Dr Matturi would appreciate old copies of the Journal (and other journals), but most of all, correspondence with psychiatrists in Britain who could encourage and support. Please write to: Dr Tamba Matturi, The Bo Clinic, PO Box 43, Bo, Sierra Leone, West Africa.

\section{Royal Patron}

May we draw readers' attention to the Registrar's report of the Winter Quarterly Meeting 1984 (Bulletin, April 1984, 8, 77) which announced that His Royal Highness the Prince of Wales has agreed to become Patron of the Royal College of Psychiatrists. 